\title{
A MULTI-COUNTRY COMPARISON OF THE LINKAGES BETWEEN INFLATION AND EXCHANGE RATE COMPETITIVENESS
}

by

Steven B. Kamin

August 1997

BANK FOR INTERNATIONAL SETTLEMENTS

Monetary and Economic Department

BASLE 
BIS Working Papers are written by members of the Monetary and Economic Department of the Bank for International Settlements, and from time to time by outside economists, and are published by the Bank. The papers are on subjects of topical interest and are technical in character. The views expressed in them are those of their authors and not necessarily the views of the BIS.

(C) Bank for International Settlements 1997

CH-4002 Basle, Switzerland

Also available on the BIS World Wide Web site (http://www.bis.org).

All rights reserved. Brief excerpts may be reproduced or translated provided the source is stated.

ISSN 1020-0959 


\title{
A MULTI-COUNTRY COMPARISON OF THE LINKAGES BETWEEN INFLATION AND EXCHANGE RATE COMPETITIVENESS *
}

by

\author{
Steven B. Kamin
}

August 1997

\begin{abstract}
This paper describes research comparing the response of inflation to changes in exchange rate competitiveness in various regions of the world. The paper first presents evidence that an empirical relationship between the rate of inflation and the level of the real exchange rate, which was documented for Mexico in previous research by the author, holds for a large set of other countries as well. This result may pose a dilemma for policy-makers, since it implies that it may not be possible to achieve low inflation and a high export competitiveness simultaneously. The paper then demonstrates that the responsiveness of inflation to the real exchange rate has been much higher in Latin America than in Asian or industrialised countries. This difference in inflationary responsiveness is not fully explained either by the prior history of inflation or by the extent of openness to foreign trade. It is possible that the lower responsiveness of inflation to the real exchange rate in Asia than in Latin America is what has allowed the Asian countries to remain more consistently focused on maintaining competitiveness and export growth.
\end{abstract}

\footnotetext{
I wish to thank Palle Andersen, Joseph Bisignano, Claudio Borio, Sean Craig, Stefan Gerlach, Frank Smets and members of the BIS Workshop for very useful advice and encouragement. I am also indebted to Marc Klau for superb and enthusiastic research assistance, and to Liliana Morandini for her cheerful and professional typing and overseeing of the publication.
} 



\section{Contents}

Introduction

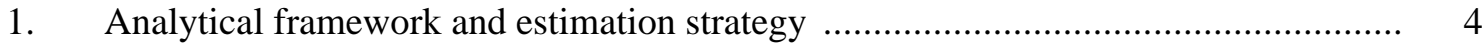

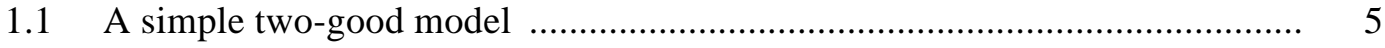

1.2 Derivation of the estimated inflation equation .................................... 9

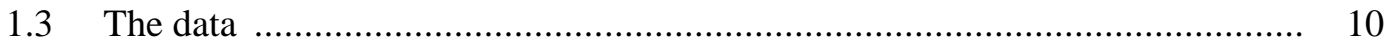

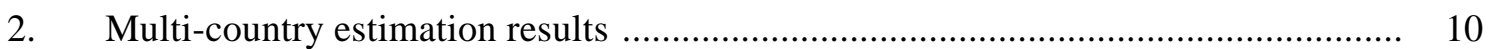

3. Accounting for differences in inflation behaviour ...................................... 14

3.1 The role of productivity growth effects ........................................... 14

3.2 The role of inflation history and economic openness ............................... 16

Conclusion

Appendix: Derivation of the supply curve for home goods

References 



\section{Introduction}

This paper describes research comparing the response of inflation to changes in exchange rate competitiveness in various regions of the world. It is motivated by several objectives. The first of these is to determine whether an empirical relationship between the rate of inflation and the level of the real exchange rate, which was documented for Mexico by Kamin (1996), also holds for other countries. It is well known that a one-time devaluation (revaluation) of the nominal exchange rate may result in a temporary increase (decrease) in inflation. It is less widely understood, particularly among policymakers and other economic practitioners, that keeping the level of the real exchange rate depreciated (appreciated) for an extended period may lead to a sustained increase (decrease) in inflation. ${ }^{1}$ To the extent that such a relationship holds, it poses difficulties for policy-makers, since it implies that there may be a conflict, at least in the short and medium-term, between the pursuit of price stability and maintaining external competitiveness. As indicated in Chart 1 (and as substantiated by formal statistical tests in Kamin (1996)), such a linkage between inflation and the real exchange

Chart 1

Inflation and competitiveness in Mexico

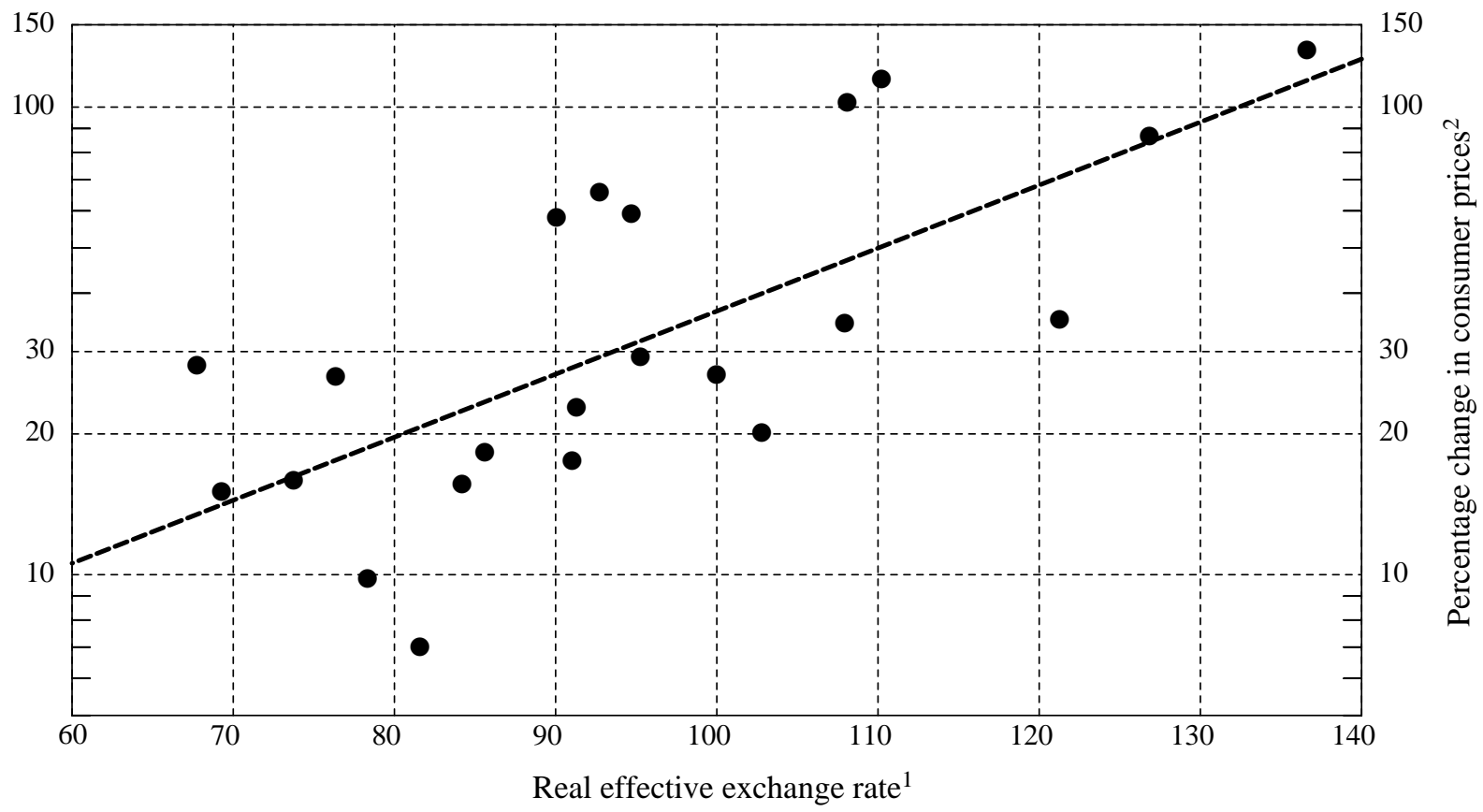

Note: The data points represent individual years between 1975 and 1996 (annual averages).

${ }^{1}$ In terms of relative consumer prices; $1990=100$. An increase indicates a depreciation. ${ }^{2}$ Logarithmic scale.

1 The existence of linkages between the level of the real exchange rate and the rate of inflation has been more commonly established in the theoretical literature. In particular, the literature on real exchange rate targeting has emphasised the danger of explosive inflationary paths that can result when policy-makers attempt to target the real exchange rate at a misaligned level (see Adams and Gros (1986), Montiel and Ostry (1991) and Calvo et al. (1994)). 
rate appears to hold for Mexico, but it is not clear whether this relationship operates in other countries as well. ${ }^{2}$

The second objective of this paper is to ascertain whether, assuming that a relationship between inflation and the real exchange rate does apply to other countries besides Mexico, the parameters of this relationship differ systematically from region to region. The motivation for this question is the observation that inflation and the real exchange rate have evolved in very different ways in Latin America and Asia in the past few decades. As indicated in the upper left-hand panel of Chart 2, many Latin American countries substantially devalued their exchange rates with the onset of the debt crisis in the early 1980s in order to reduce large current account deficits - this was associated with a marked surge in inflation. In response, some of these countries subsequently fixed their exchange rates, leading to sharp reductions in inflation but substantial real appreciations. In Mexico, this appreciation proved unsustainable, and a large devaluation boosted inflation rates in 1995 and 1996.

In Asia, real exchange rates also depreciated substantially in the 1980s, reflecting the need to reduce large current account deficits in some cases, as well as the fall of the US dollar later in the decade. In contrast to the Latin American experience, however, the response of inflation to devaluation in Asia was relatively subdued. While Asian inflation rates picked up moderately in the late 1980s, as shown in lower left-hand panel of Chart 2, they remained well below average levels at the start of the decade. Perhaps as a result, the Asian countries kept their currencies relatively depreciated in order to encourage exports, and did not experience the sharp real appreciation registered in Latin America. ${ }^{3}$

The different experiences of Latin America and Asia point to the possibility of systematic differences in the relationship between inflation and the real exchange rate, as summarised in the right-hand panels of Chart 2. Assuming that these differences stand up to formal statistical testing, a third objective of this paper is to analyse the factors that might contribute to different inflationary responses to competitiveness. One potential factor is prior inflation history - in countries with histories of high inflation, inflationary shocks may translate more quickly into changes in inflation expectations and in wage and price contracts, leading to more rapid changes in actual inflation.

2 There is some, albeit unsystematic, evidence of this relationship holding for other countries. Edwards (1989) finds that countries using crawling-peg exchange rate policies to maintain real devaluations had higher rates of inflation compared with those countries implementing one-time devaluations. Kiguel (1992) argues that in Colombia in 1990, as well as in Mexico during the 1980s, surges in inflation reflected undervalued exchange rates. Calvo et al. (1994) identify correlations between the temporary components of inflation and the real exchange rate in Brazil, Chile and Colombia.

3 An alternative (albeit complementary) explanation for regional differences in exchange rate policy is that in Asia, overvaluation disadvantaged large numbers of rural tradables producers, whereas in Latin America only a relatively few large landowners were hurt by overvaluation, while large numbers of urban workers benefited (at least in the short run). Therefore, Asian policy focused on keeping the real exchange rate competitive, while Latin American governments favoured overvaluation (see Sachs (1985) and Edwards (1995)). 
Chart 2

\section{Inflation and real effective exchange rates ${ }^{1}$}
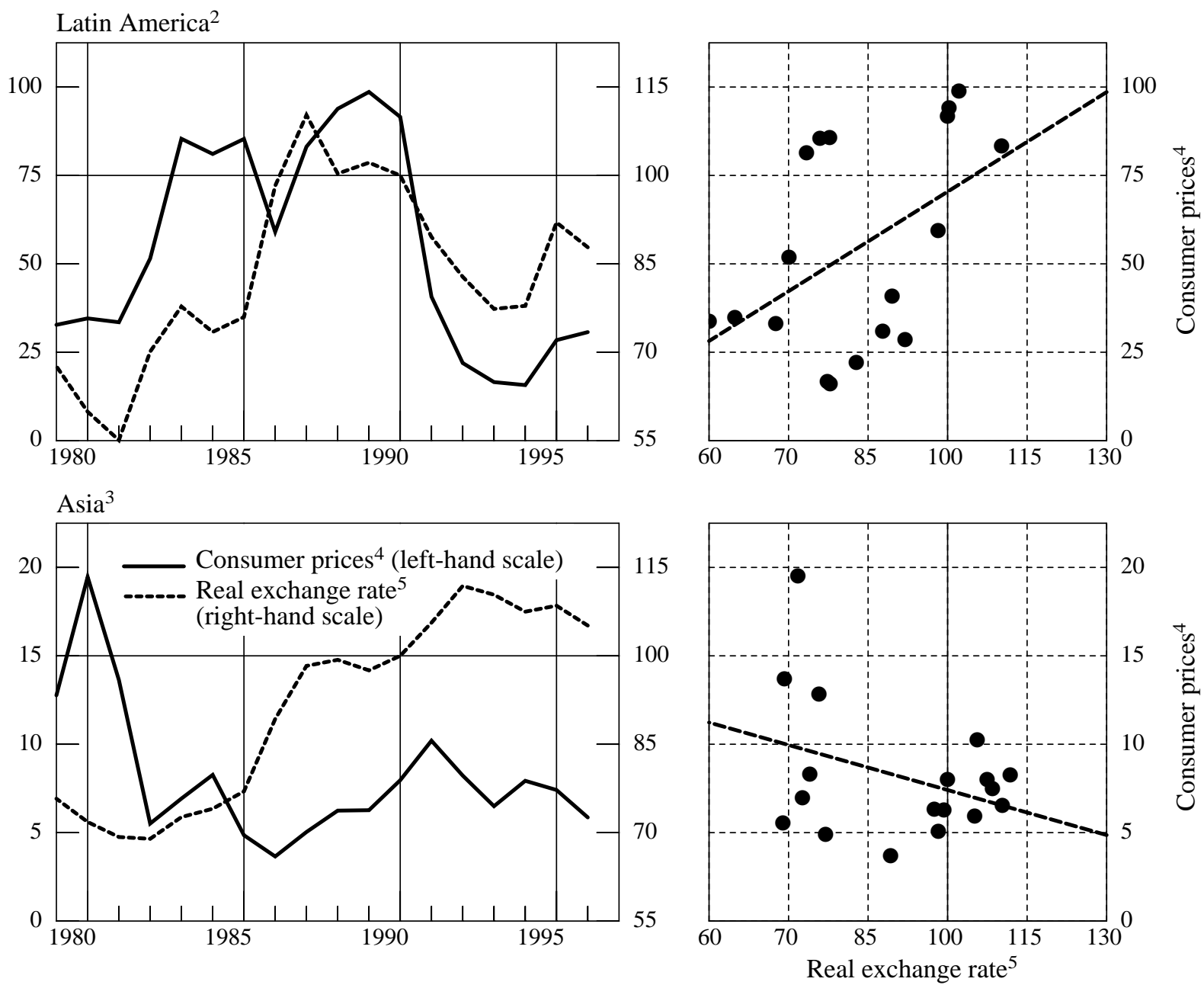

${ }^{1}$ Weighted averages, calculated using 1990 GDP and PPP exchange rates. $\quad{ }^{2}$ Argentina, Bolivia, Chile, Colombia, Ecuador, Mexico, Uruguay, Venezuela. ${ }^{3}$ Hong Kong, India, Indonesia, Korea, Malaysia, the Philippines, Singapore, Taiwan, Thailand. ${ }^{4}$ Annual percentage changes. ${ }^{5}$ In terms of relative consumer prices; $1990=100$. An increase indicates a depreciation.

Another potential factor is the openness of the economy - the more open the economy, the more likely it is that a change in the exchange rate will lead to changes in costs and hence in prices.

The plan of this paper is as follows. Section 1 presents a simple analytical framework to show how a linkage might operate between the rate of inflation and the level of the real exchange rate, and derives an econometric equation to estimate this relationship. Section 2 applies this equation to countries in three regions - Latin America, Asia, and the industrialised world. In Section 3, differences between the regions in the estimated responsiveness of inflation to the real exchange rate are evaluated. This section first considers whether these differences in estimated responsiveness might be spurious, perhaps resulting from the effect of differences in regional productivity growth on the econometric estimates. It then examines the role of prior inflation history and of openness in conditioning the responsiveness of inflation to exchange rates. Section 4 summarises the main results of the research. 


\section{Analytical framework and estimation strategy}

Table 1 reproduces the inflation equation estimated for Mexico by Kamin (1996). It differs from a conventional output-gap-based Phillips curve, shown below in equation (1), in two respects.

$\Delta \log P=\alpha+\beta \log \left(Y / Y^{*}\right)+\gamma \Delta \log P_{-1}$

$P \quad:$ CPI

$Y$ : real output

$Y^{*}:$ potential real output

$\Delta$ : difference operator

Table 1

Estimation results for monthly inflation model for Mexico

Dependent variable $\Delta \log (P)$

\begin{tabular}{|c|c|c|}
\hline & OLS & IV \\
\hline Constant & $\begin{array}{c}0.16 \\
(4.94)\end{array}$ & $\begin{array}{c}0.16 \\
(4.82)\end{array}$ \\
\hline$R E R_{-1}$ & 0.04 & 0.04 \\
\hline & $\begin{array}{c}(4.95) \\
0.08\end{array}$ & $\begin{array}{c}(4.82) \\
0.08\end{array}$ \\
\hline & $(4.20)$ & $(4.20)$ \\
\hline$\Delta \log (P)_{-1}$ & $\begin{array}{c}0.50 \\
(7.88)\end{array}$ & $\begin{array}{c}0.51 \\
(7.23)\end{array}$ \\
\hline$\Delta \log (P)_{-2}$ & $\begin{array}{c}0.18 \\
(3.11)\end{array}$ & $\begin{array}{c}0.18 \\
(3.04)\end{array}$ \\
\hline$\Delta \log (P)_{-11}$ & $\begin{array}{c}0.21 \\
(3.51)\end{array}$ & $\begin{array}{c}0.21 \\
(3.52)\end{array}$ \\
\hline$\Delta \log (P)_{-12}$ & $\begin{array}{c}-0.21 \\
(-3.46)\end{array}$ & $\begin{array}{c}-0.21 \\
(-3.47)\end{array}$ \\
\hline$\Delta \log (E)$ & $\begin{array}{c}0.08 \\
(8.04)\end{array}$ & $\begin{array}{c}0.07 \\
(2.64)\end{array}$ \\
\hline$\Delta \log (E)_{-1}$ & $\begin{array}{l}-0.02 \\
(-1.66)\end{array}$ & $\begin{array}{c}-0.02 \\
(-1.45)\end{array}$ \\
\hline$\Delta \log (E)_{-3}$ & $\begin{array}{c}0.03 \\
(2.66)\end{array}$ & $\begin{array}{c}0.03 \\
(2.61)\end{array}$ \\
\hline$\Delta \log (E)_{-} 9$ & $\begin{array}{c}0.02 \\
(2.12)\end{array}$ & $\begin{array}{c}0.02 \\
(2.10)\end{array}$ \\
\hline$\Delta \log \left(P^{*}\right)_{-2}$ & $\begin{array}{c}0.54 \\
(2.74)\end{array}$ & $\begin{array}{c}0.53 \\
(2.74)\end{array}$ \\
\hline $\begin{array}{l}\text { Adjusted } R \text { squared } \\
\text { Reoression standard error }\end{array}$ & $\begin{array}{l}0.90 \\
0.008\end{array}$ & 0.90 \\
\hline Durbin-Watson statistic & 2.05 & 2.05 \\
\hline
\end{tabular}

Note: t-statistics in parentheses. $P=$ Mexico CPI; $P^{*}=\mathrm{US} \mathrm{CPI} E=$ nominal exchange rate (pesos/dollar); RER= real exchange rate; $Y G A P=$ output gap (based on industrial production).

Source: Kamin (1996). 
First, and less importantly, the equation reproduced in Table 1 incorporates lags of foreign inflation and nominal exchange rate depreciation in order to better capture the dynamics of inflation in a monthly model of a small open economy. Second, the equation includes not only a measure of the output gap but also the level of the real exchange rate, defined so that increases represent depreciations. As may be seen, the coefficient on the level of the real exchange rate is highly significant, even when lagged inflation and the rate of nominal exchange rate depreciation are controlled for. Moreover, these results are not changed by IV estimation of the equation, which is designed to control for the possible endogeneity of the contemporaneous rate of nominal exchange rate depreciation.

In sum, the equation reproduced in Table 1 confirms, at least for Mexico, the significance of the linkage between the rate of inflation and the level of the real exchange rate illustrated in Chart 1 . How can such a linkage be understood? There are a variety of theoretical models that imply a relationship between competitiveness and inflation. The following is a very simple example of such a model, designed to provide the most basic understanding of the role played by the real exchange rate in the determination of inflation in open economies.

\subsection{A simple two-good model}

Assume a small open economy that produces, consumes and exports a home good $(H)$ and imports and consumes a foreign good $(F)$. The price of the foreign good $P_{F}$ is determined by the exchange rate $E$ (local currency per dollar) and the (exogenous) foreign currency price of foreign goods $P_{F}^{*}$. The price of home goods $P_{H}$ is determined by equilibrium in the market for home goods.

To determine the equilibrium price of home goods, we start with producers that maximise profits by choosing the level of labour use $L$, and hence the level of output $Q_{H}$, subject to declining marginal products of labour for a given level of capacity or potential output $\bar{Q}_{H} ;{ }^{4}$ accordingly, the demand for labour declines with increases in the real product wage $W / P_{H}$. Conversely, the supply of labour rises with the real consumption wage $W / P$, where the consumer price level $P$ is a weighted average of home goods prices $P_{H}$ and foreign goods prices $P_{F}$.

Based on these assumptions, we can derive a supply curve for home goods as a function of the relative price, or equivalently, the real exchange rate, $P_{\mathrm{F}} / P_{\mathrm{H}} \cdot\left(\eta_{a, b}\right.$ refers to the elasticity of $a$ with respect to $b$.) Increases in foreign prices raise the cost of living $P$ and hence wages $W$, thereby

4 As explained in the appendix, $\bar{Q}_{H}$ may be thought of as representing the quantity of home goods that can be produced with the existing capital stock and technology, as well as with the "normal" or trend level of the labour supply. Insofar as the actual supply of labour may differ from its trend level, depending on the level of the real wage, so may actual home goods output differ from its potential level. 
raising the real product wage in the home goods sector, $W / P_{H}$. This causes the supply of home goods to decline. A full derivation is provided in the appendix.

$$
\begin{aligned}
& S_{H}=S_{H}\left(P_{F} / P_{H} ; \bar{Q}_{H}\right) \\
& \eta_{S_{H}, P_{F} / P_{H}}<0 \text { and } \eta_{S_{H}, \bar{Q}_{H}}>0
\end{aligned}
$$

The demand for home goods by residents $D_{\mathrm{H}}$ and by foreigners $D_{H}^{*}$ are assumed to depend on both relative prices and total domestic demand or absorption $A$ and $A^{*}$. For simplicity, assume that foreign and domestic demand for home goods share the same elasticity with respect to relative prices, and that their elasticity with respect to absorption is unity in both cases.

$$
\begin{aligned}
& D_{H}=D_{H}\left(P_{F} / P_{H} ; A\right) \\
& D_{H}^{*}=D_{H}^{*}\left(P_{F} / P_{H} ; A^{*}\right) \\
& \eta_{D_{H}, P_{F} / P_{H}}=\eta_{D_{H}^{*}, P_{F} / P_{H}}>0 \\
& \eta_{D_{H}, A}=\eta_{D_{H}^{*}, A^{*}}=1
\end{aligned}
$$

Equilibrium in the market for home goods requires that supply equal the sum of domestic and foreign demand:

$$
S_{H}=D_{H}+D_{H}^{*}
$$

We log-differentiate equation (4), allowing for changes in the level of potential output $\bar{Q}_{H}$ as well. The differential in the growth of foreign and home goods prices - equivalently, the change in the real exchange rate - can then be expressed as a simple negative function of the weighted average growth in domestic and foreign absorption relative to potential home goods output. ${ }^{5}$ In other words, increases in absorption relative to domestic potential output raise the price of home goods relative to foreign goods, thereby appreciating the real exchange rate.

$$
\begin{aligned}
& \left(\hat{P}_{F}-\hat{P}_{H}\right)=-\varepsilon\left[\left(\delta \hat{A}+(1-\delta) \hat{A}^{*}\right)-\hat{\bar{Q}}_{H}\right]=\varepsilon\left[\hat{A}^{\prime}-\hat{\bar{Q}}_{H}\right] \\
& \delta=\frac{D_{H}}{\left(D_{H}+D_{H}^{*}\right)} \\
& \varepsilon=\frac{1}{\eta_{D_{H}, P_{F} / P_{H}}-\eta_{S_{H}, P_{F} / P_{H}}}>0
\end{aligned}
$$

5 The simplicity of this function depends upon the assumption that $\eta_{S_{H}}, \bar{Q}_{H}=1$. This can be shown to hold if increases in potential output growth $\hat{\bar{Q}}_{H}$ result from equiproportionate increases in capital and labour. 
Based on equation (5), the relationship between the log-level of the real exchange rate and the loglevel of the gap between absorption and potential output is shown below; $\left(\tilde{P}_{F} / \tilde{P}_{H}\right)$ represents the value of the real exchange rate consistent with home goods equilibrium:

$\log \left(\tilde{P}_{F} / \tilde{P}_{H}\right)=\psi-\varepsilon \log \left(A^{\prime} / \bar{Q}_{H}\right)$

$\psi=$ constant term

Note that equation (6) does not specify which variable - home goods prices, the nominal exchange rate or domestic absorption - adjusts when the home goods market departs from equilibrium. It is our hypothesis that, in the first instance, the nominal exchange rate and absorption are determined primarily by expectations and by fiscal and monetary policies, while the price of home goods moves in response to deviations between actual and equilibrium ratios of foreign to home goods prices. Equation (7) depicts a partial adjustment process, based on this reasoning, in which changes in home goods prices are proportional to the gap between the actual ratio of foreign goods prices to home goods prices and the equilibrium ratio, $\left(\tilde{P}_{F} / \tilde{P}_{H}\right){ }^{6}$

$\Delta \log \left(P_{H}\right)_{t}=\lambda\left(\log \left(P_{F} / P_{H}\right)_{t-1}-\log \left(\tilde{P}_{F} / \tilde{P}_{H}\right)_{t-1}\right)$

$\lambda>0$

Substituting equation (6) into equation (7), the rate of inflation of home goods prices can be expressed as a function of both the ratio of absorption to potential output and the level of the ratio of foreign to home goods prices.

$\Delta \log \left(P_{H}\right)_{t}=\lambda \log \left(P_{F} / P_{H}\right)_{t-1}-\lambda \psi+\lambda \varepsilon \log \left(A^{\prime} / \bar{Q}_{H}\right)_{t-1}$

Equation (8) constitutes the primary rationale for the relationship between the rate of inflation and the level of the real exchange rate documented in Chart 1 and Table $1 .^{7}$ Intuitively, a depreciation of the real exchange rate relative to the level that clears the market for home goods, by raising foreign goods prices relative to home goods prices, shifts demand toward home goods while raising wages and hence production costs - both of these forces lead to increases in home goods prices until the real exchange rate reverts to its original level.

The relationship between the real exchange rate and inflation can also be shown graphically, as in Figure 1. For a given level of potential output, the HH curve represents the locus of points that lead to equilibrium in the home goods market: increases in absorption $A^{\prime}$ raise the demand

6 A similar partial adjustment formulation is employed by Adams and Gros (1986) in their analysis of real exchange rate targeting.

7 Strictly speaking, $\Delta \log \left(P_{H}\right)$ represents only the home goods component of CPI inflation, while $P_{F} / P_{H}$ is not exactly the same measure as the multilateral real effective exchange rate shown in Chart 1 . As we show in the next section, however, the rate of change of home goods prices is likely to be highly correlated with CPI inflation, while the ratio of foreign to home goods prices is a monotonic function of the multilateral real effective exchange rate. 
for home goods, causing the real equilibrium exchange rate to appreciate. Points above the HH curve, as at $\mathrm{X}_{0}$, represent points of excess demand for home goods, since the ratio of foreign to home goods prices exceeds its equilibrium level; at such points, home goods prices rise, causing, for a given nominal exchange rate and absorption, the real exchange rate to appreciate to $\mathrm{X}_{1}$. Conversely, points below the $\mathrm{HH}$ curve, such as $\mathrm{Y}_{0}$, represent points of excess supply of home goods, causing declines in home goods prices until the real exchange rate depreciates to $Y_{1}$.

\section{Figure 1}

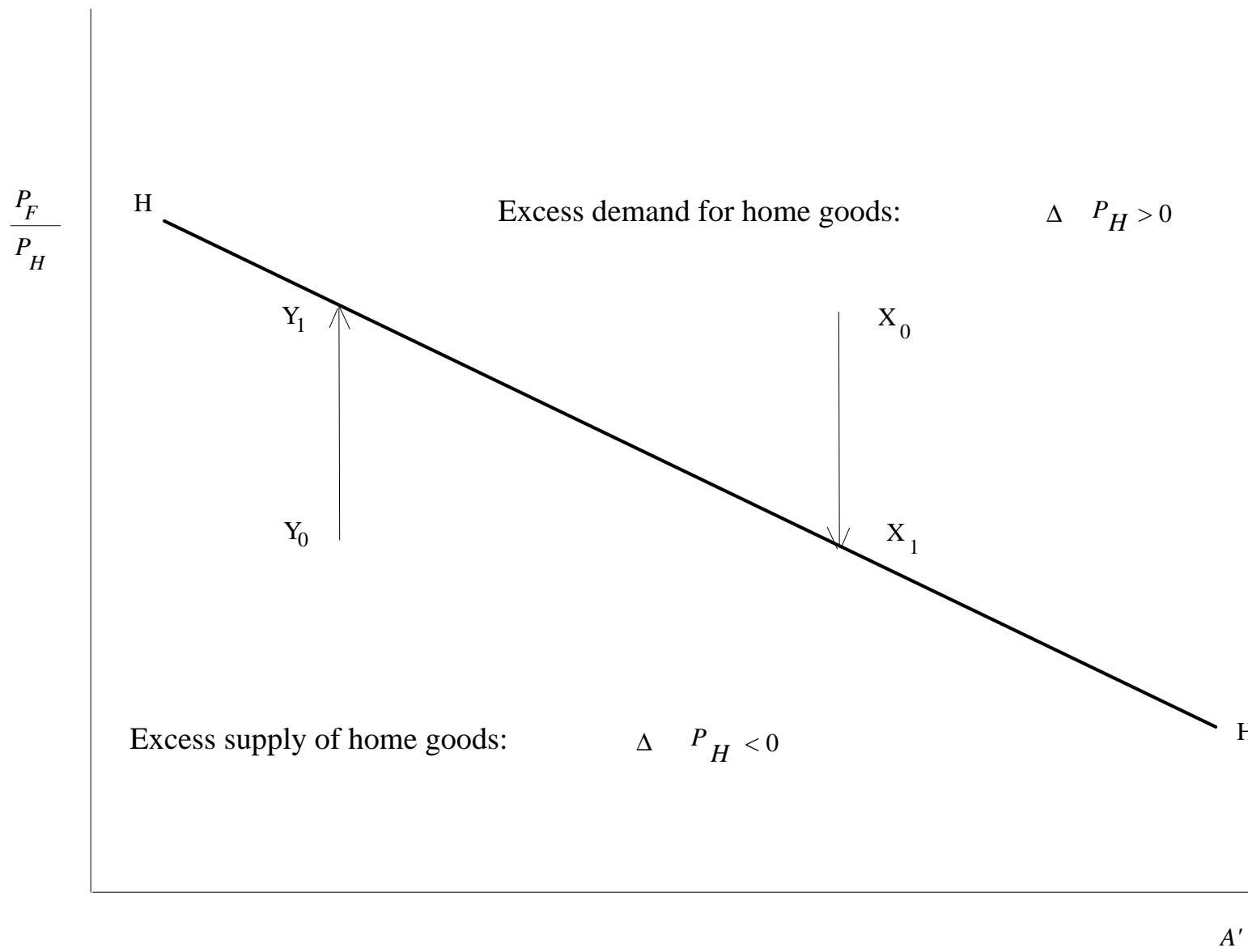

It is important to keep in mind that the $\mathrm{HH}$ curve represents the locus of equilibrium points for the home goods market only - being on the HH curve does not necessarily lead to equilibrium in the balance of payments. For example, Kamin (1996) argues that Mexico, prior to its 1994 devaluation, was in internal balance - that is, on the HH curve - even as the real exchange rate was excessively appreciated compared with the level needed for external balance. Hence, while it is the real exchange rate (and absorption) relative to the $\mathrm{HH}$ curve that determines the rate of inflation, being on the $\mathrm{HH}$ curve by no means guarantees balanced payments flows or exchange rate sustainability.

It is also worth noting that equation (8), like the conventional Phillips curve, does not include such traditional determinants of inflation as monetary and fiscal policies. While monetary and fiscal policies may be fundamental causes of inflation, they are viewed - as in the standard textbook 
analysis - as causing inflation through their effect on inflation's proximate determinants, the exchange rate and absorption. For example, an easing of monetary policy may lead to higher inflation by increasing aggregate demand (raising $A^{\prime}$ ) and by depreciating the exchange rate (thereby raising $P_{F}$ ); therefore, while monetary policy itself is not captured by equation (8), both of its important effects are. In this sense, equation (8) represents a narrow description of the inflation process, focusing only on its proximate determinants. Even so, it may yield important insights into the behaviour of inflation in open economies, just as the expectations-augmented Phillips curve remains an important tool for analysis and forecasting in more closed-economy settings.

\subsection{Derivation of the estimated inflation equation}

There are a number of alterations to equation (8) that must be made before it can be estimated econometrically. First, our data are for CPI inflation - a weighted average of home and foreign goods inflation - not home goods price inflation. Using small letters to indicate logs:

$\Delta p=\alpha \Delta p_{H}+(1-\alpha) \Delta p_{F}$

Therefore, substituting the expression for home goods inflation in equation (8) into equation (9):

$\Delta p_{t}=-\alpha \lambda \psi+\alpha \lambda\left(p_{F}-p_{H}\right)_{t-1}+\alpha \lambda \varepsilon\left(a^{\prime}-\bar{q}_{H}\right)_{t-1}+(1-\alpha) \Delta p_{F_{t}}^{*}+(1-\alpha) \Delta e_{t}$

Additionally, the multilateral real effective exchange rate log of $(R E R)$ used in our study is a function of the log of the ratio of foreign to home goods prices specified in the theoretical model:

$R E R=\frac{P^{*} . E}{P}=\frac{P_{F}}{P_{H}^{\alpha} P_{F}^{1-\alpha}}=\left(\frac{P_{F}}{P_{H}}\right)^{\alpha}$

Replacing the ratio of foreign to home goods prices with the $R E R$ yields:

$\Delta p_{t}=-\alpha \lambda \psi+\lambda r e r_{t-1}+\alpha \lambda \varepsilon\left(a^{\prime}-\bar{q}_{H}\right)_{t-1}+(1-\alpha) \Delta p_{t}^{*}+(1-\alpha) \Delta e_{t}$

For many of the countries in our sample, accurate times series of sufficient length on domestic absorption are not available. Therefore, we use actual real GDP $\left(Q_{H}\right)$ as a proxy for weighted-average absorption $\left(A^{\prime}\right)$, so that the ratio of absorption to potential GDP is proxied by the output gap. A comparison of absorption and GDP in countries where both of these series are available confirms that the two series are highly correlated.

Finally, we allow for the possibility that the rate of inflation may show persistence by including a lagged dependent variable. Therefore, the final estimating equation becomes:

$\Delta p_{t}=-\alpha \lambda \psi+\lambda \operatorname{rer}_{t-1}+\alpha \lambda \varepsilon\left(q_{H}-\bar{q}_{H}\right)_{t-1}+(1-\alpha) \Delta p_{t}{ }_{t}+(1-\alpha) \Delta e_{t}+\beta \Delta p_{t-1}$

Note that this equation is a more general, open-economy version of the conventional Phillips curve model. In cases where the coefficients on $\Delta e, \Delta p^{*}$ and rer are zero, the model collapses 
to the Phillips curve. Also, analogously to the conventional expectations-augmented Phillips curve, it can be shown that, providing the coefficients on $\Delta p_{-1}$ and $\Delta e$ sum to unity, there is no stable long-run trade-off between the level of the real exchange rate and the rate of inflation. Just as attempts to keep unemployment below its natural rate may induce continuous rising inflation in a conventional Phillips curve model, so may attempts to keep the real exchange rate more depreciated than its market-clearing rate, for a given output gap, lead to ever-increasing inflation in this expanded framework. ${ }^{8}$

\subsection{The data}

The study is based on annual data for the period 1970 to 1996 , subject to availability. The data were drawn from the BIS database. The variables used include:

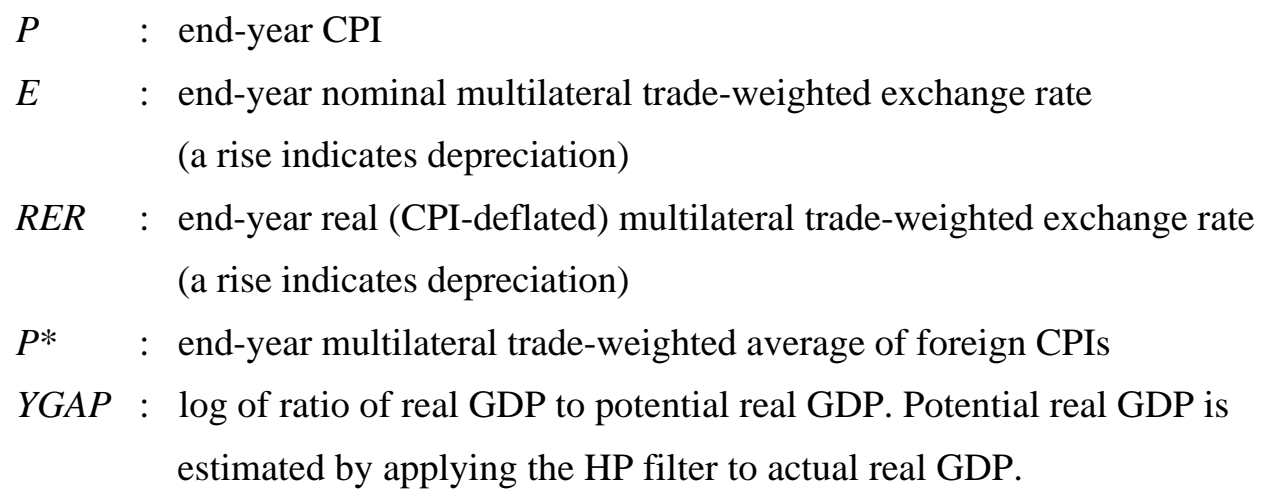

Data from the following countries were used.

Asia: $\quad$ Hong Kong, India, Indonesia, Korea, Malaysia, the Philippines, Singapore, Taiwan, Thailand.

Latin America: Argentina, Bolivia, Brazil, Chile, Colombia, Ecuador, Mexico, Uruguay, Venezuela.

Industrialised: Australia, Austria, Belgium, Canada, Denmark, Finland, France, Germany, Greece, Ireland, Italy, Japan, the Netherlands, New Zealand, Portugal, Spain, Sweden, Switzerland, the United Kingdom, the United States.

\section{Multi-country estimation results}

Equation (13) was estimated using pooled data for all of the countries listed above, as well as in separate regressions for the different regions, using "fixed effects" regressions. These

8 This is consistent with the result derived by Adams and Gros (1986) that the rate of inflation is unstable under real exchange rate targeting. Conversely, the model developed by Montiel and Ostry (1991) shows that an undervalued real exchange rate target leads to a permanent, but stable, higher rate of inflation. 
regressions allow the intercept term to be estimated separately for each country, but constrain all slope coefficients to be the same. (This is equivalent to specifying the dependent variable in terms of deviations of inflation from country means.) The estimation results are shown in Table 2. For each region, the equation was estimated both OLS and, to control for the endogeneity of the contemporaneous change in the nominal exchange rate, IV; however, in almost all instances, the use of IV estimation instead of OLS made little difference to the results. ${ }^{9}$

Table 2

\section{Fixed effects panel regressions - annual data}

Dependent variable: $\Delta \log (P)$

\begin{tabular}{|l|c|c|c|c|c|c|c|c|}
\hline \multirow{4}{*}{$\Delta$} & \multicolumn{2}{|c|}{ All countries } & \multicolumn{2}{c|}{ Latin America } & \multicolumn{2}{c|}{ Asia } & \multicolumn{2}{c|}{ Industrialised } \\
\cline { 2 - 8 }$\Delta \log (P)_{-1}$ & OLS & IV & OLS & IV & OLS & IV & OLS & IV \\
\cline { 2 - 8 }$\Delta \log \left(P^{*}\right)$ & 0.21 & 0.19 & 0.19 & 0.18 & 0.16 & 0.19 & 0.34 & 0.44 \\
& $(16.82)$ & $(14.04)$ & $(7.56)$ & $(7.17)$ & $(2.55)$ & $(2.48)$ & $(10.41)$ & $(11.47)$ \\
$\Delta \log (E)$ & 0.94 & 0.94 & 0.92 & 0.95 & 0.93 & 0.35 & 0.67 & 0.56 \\
& $(19.44)$ & $(16.74)$ & $(8.61)$ & $(8.67)$ & $(7.76)$ & $(2.28)$ & $(14.68)$ & $(8.09)$ \\
$\log (R E R)_{-1}$ & 0.70 & 0.72 & 0.75 & 0.75 & 0.16 & 0.16 & 0.15 & 0.11 \\
& $(60.75)$ & $(42.89)$ & $(32.61)$ & $(23.47)$ & $(4.29)$ & $(2.80)$ & $(9.30)$ & $(5.76)$ \\
$Y G A P_{-1}$ & 0.17 & 0.26 & 0.26 & 0.30 & 0.04 & 0.04 & 0.08 & 0.07 \\
& $(10.27)$ & $(11.85)$ & $(5.53)$ & $(5.94)$ & $(2.10)$ & $(1.88)$ & $(7.33)$ & $(5.56)$ \\
& 0.31 & 0.28 & 0.61 & 0.45 & 0.56 & 0.40 & 0.18 & 0.16 \\
& $(3.55)$ & $(2.71)$ & $(1.97)$ & $(1.43)$ & $(4.81)$ & $(3.42)$ & $(4.51)$ & $(4.51)$ \\
\hline
\end{tabular}

Note: t-statistics in parentheses. $P=$ end-year $\mathrm{CPI} ; P^{*}=$ foreign weighted $P ; E=$ multilateral nominal effective exchange rate (up means depreciate); $R E R=$ multilateral real effective exchange rate (up means depreciate); $Y G A P=\log ($ real $(\mathrm{GDP})$ - $\log$ (potential real GDP).

Instruments for IV: $\Delta \log (P)_{-1}, \Delta \log \left(P^{*}\right), \Delta \log (E)_{-1}, \log (R E R)_{-1}, Y G A P_{-1}$, terms of trade (lagged, if panel contains industrialised countries), US real short-term interest rate (lagged if panel contains industrialised countries), lagged change in ratio of current account to GDP.

Focusing first on the equation estimated for all countries, all of the estimated coefficients are statistically significantly different from zero and of the expected sign. Increases in foreign price inflation lead to a proportionate increase in domestic inflation, while increases in nominal exchange rate depreciation and in the output gap also boost inflation. ${ }^{10}$ The coefficient on the lagged dependent variable is relatively low, indicating a fairly low degree of persistence in inflation - this may in part

9 The rate of nominal exchange rate depreciation was the only variable instrumented for, as the rate of foreign inflation is exogenous to nearly all of the economies in the sample, and the lagged values of inflation, the real exchange rate and the output gap are predetermined. In principle, if the error term is serially correlated, there could be a correlation between the error and either the lagged real exchange rate or the lagged output gap that could induce simultaneity bias. In practice, the presence of the lagged dependent variable reduces the probability of this occurring, particularly given that the data are annual. Kamin (1996) finds no evidence of error autocorrelation in the monthly inflation equation for Mexico.

10 Theoretically, as shown in equation (13), nominal exchange rate depreciation and foreign price inflation should have the same impact on domestic inflation. In practice, however, their estimated coefficients are quite different, so no attempt is made to impose the theoretical parameter constraint. 
reflect the fact that annual data are being used, thereby reducing the importance of dynamics compared with higher-frequency data. Finally, the coefficient on the log-level of the real exchange rate is of the correct sign and is highly significant: a depreciation of the real exchange rate, holding all else constant - including the rate of nominal exchange rate depreciation - leads to a higher rate of CPI inflation.

The results based on the full country sample apply, broadly speaking, to the separate regional regressions, but there are important differences. In particular, the coefficients on both the real exchange rate and the rate of nominal exchange rate depreciation are much higher for Latin America than for Asia or the industrialised countries. The higher coefficient on the level of the real exchange rate is of particular interest. It suggests that in Latin America, attempts to maintain the real exchange rate at a highly depreciated level are more likely to lead to higher inflation than is the case in Asia or in the industrialised countries. This difference could help to explain why Asian countries have been able to maintain the competitiveness of their exchange rates on a consistent basis, while in many Latin American countries the focus of macroeconomic policy has tended to alternate between supporting external performance, at the cost of price stability, and reducing inflation, at the cost of external competitiveness.

The first column of Table 3 presents a formal test of the statistical significance of differences in coefficient values across regions. Each of the explanatory variables in the basic model is interacted both with a dummy variable for Asian countries $(=1$ if Asian, $=0$ if not $)$ and a dummy variable for industrialised countries $(=1$ if industrialised, $=0$ if not). Therefore, the non-interacted coefficients represent those for Latin America alone, while the coefficients on the interaction terms represent the difference between the coefficient applying to that region and the coefficient for Latin America. The results indicate very strongly that the responsiveness of inflation both to the rate of nominal exchange rate depreciation and to the level of the real exchange rate is much higher in Latin America than in Asia or the industrialised countries.

Notwithstanding recent strong interest in comparing the economic performance of Latin American and Asian countries, there has been relatively little research focusing specifically on differences in the inflationary process in the two regions. It may be worthwhile to compare the results shown in Table 2 with those of two recent cross-country studies of inflation summarised in the IMF's October 1996 World Economic Outlook (WEO). The first of these studies compares the responsiveness of inflation to the output gap in Asian and Latin American countries. ${ }^{11}$ It finds this responsiveness to be statistically significant in most Asian countries, but only in a few Latin American countries. This is consistent with our findings, shown in Table 2, that the output gap is, at best, only barely statistically significant for Latin America. On the other hand, the size of the coefficient on the output gap is larger in Latin America than in the other regions, as also indicated in

11 The results are based on a methodology described in Coe and McDermott (1996). 
Table 3, leaving some ambiguity as to whether or not output gaps genuinely affect inflation in Latin America.

Table 3

\section{Tests for regional differences}

Dependent variable: $\Delta \log (P)$

\begin{tabular}{|c|c|c|c|}
\hline \multirow{3}{*}{$\Delta \log (P)_{-1}$} & (1) & $(2)^{1}$ & $(3)^{2}$ \\
\hline & 0.19 & 0.18 & 0.18 \\
\hline & (16.95) & (14.64) & (13.66) \\
\hline \multirow{2}{*}{$\Delta \log \left(P^{*}\right)$} & 0.92 & 0.94 & 1.00 \\
\hline & $(19.30)$ & (20.31) & (19.91) \\
\hline \multirow[t]{2}{*}{$\Delta \log (E)$} & 0.75 & 0.13 & 0.56 \\
\hline & (73.13) & $(1.70)$ & $(18.21)$ \\
\hline $\log (R E R)_{-1}$ & $\begin{array}{c}0.26 \\
(12.39)\end{array}$ & $\begin{array}{c}0.28 \\
(9.67)\end{array}$ & $\begin{array}{c}0.25 \\
(11.24)\end{array}$ \\
\hline$Y G A P_{-1}$ & $\begin{array}{c}0.61 \\
(4.42)\end{array}$ & $\begin{array}{c}0.55 \\
(4.25)\end{array}$ & $\begin{array}{c}0.49 \\
(3.70)\end{array}$ \\
\hline ASIA DUMMY х $\Delta \log (P)_{-1}$ & $\begin{array}{c}-0.00 \\
(-0.03)\end{array}$ & $\begin{array}{c}0.08 \\
(0.91)\end{array}$ & $\begin{array}{c}0.02 \\
(0.15)\end{array}$ \\
\hline ASIA DUMMY x $\Delta \log \left(P^{*}\right)$ & $\begin{array}{c}-0.08 \\
(-0.44)\end{array}$ & $\begin{array}{c}-0.04 \\
(-0.26)\end{array}$ & $\begin{array}{c}-0.58 \\
(-2.58)\end{array}$ \\
\hline$A S I A D U M M Y \times \Delta \log (E)$ & $\begin{array}{c}-0.60 \\
(-10.46)\end{array}$ & $\begin{array}{c}-0.47 \\
(-8.38)\end{array}$ & $\begin{array}{c}-0.50 \\
(-8.41)\end{array}$ \\
\hline$A S I A D U M M Y \times \Delta \log (R E R)_{-1}$ & $\begin{array}{c}-0.22 \\
(-6.82)\end{array}$ & $\begin{array}{c}-0.21 \\
(-6.71)\end{array}$ & $\begin{array}{c}-0.21 \\
(-6.11)\end{array}$ \\
\hline$A S I A D U M M Y \times Y G A P_{-1}$ & $\begin{array}{c}-0.18 \\
(-0.88)\end{array}$ & $\begin{array}{c}-0.16 \\
(-0.81)\end{array}$ & $\begin{array}{c}-0.04 \\
(-0.20)\end{array}$ \\
\hline INDUSTRIAL DUMMY x $\Delta \log (P)_{-1}$ & $\begin{array}{c}0.15 \\
(1.56)\end{array}$ & $\begin{array}{c}0.23 \\
(2.39)\end{array}$ & $\begin{array}{c}0.18 \\
(1.57)\end{array}$ \\
\hline INDUSTRIAL DUMMY x $\Delta \log \left(P^{*}\right)$ & $\begin{array}{c}-0.25 \\
(-0.74)\end{array}$ & $\begin{array}{c}-0.10 \\
(-0.63)\end{array}$ & $\begin{array}{c}-0.60 \\
(-3.06)\end{array}$ \\
\hline INDUSTRIAL DUMMY x $\Delta \log (E)$ & $\begin{array}{c}-0.59 \\
(-11.84)\end{array}$ & $\begin{array}{c}-0.45 \\
(-8.88)\end{array}$ & $\begin{array}{c}-0.52 \\
(-9.48)\end{array}$ \\
\hline INDUSTRIAL DUMMY x $\Delta \log (R E R)_{-} 1$ & $\begin{array}{c}-0.18 \\
(-4.74)\end{array}$ & $\begin{array}{c}-0.17 \\
(-4.44)\end{array}$ & $\begin{array}{c}-0.18 \\
(-4.21)\end{array}$ \\
\hline INDUSTRIAL DUMMY x YGAP-1 & $\begin{array}{c}-0.43 \\
(-2.37)\end{array}$ & $\begin{array}{c}-0.44 \\
(-2.54)\end{array}$ & $\begin{array}{c}-0.29 \\
(-1.61)\end{array}$ \\
\hline INFLATION HISTORY x log $(R E R)_{-} 1$ & - & $\begin{array}{c}0.09 \\
(6.36)\end{array}$ & $\begin{array}{c}0.02 \\
(4.94)\end{array}$ \\
\hline OPENNESS x log $(R E R)_{-1}$ & - & $\begin{array}{c}-0.02 \\
(-3.06)\end{array}$ & $\begin{array}{l}-0.00 \\
(2.57)\end{array}$ \\
\hline INFLATION HISTORY $\mathrm{x} \Delta \log (E)$ & - & $\begin{array}{c}0.39 \\
(10.38)\end{array}$ & $\begin{array}{c}0.10 \\
(8.23)\end{array}$ \\
\hline OPENNESS x $\Delta \log (E)$ & - & $\begin{array}{c}0.15 \\
(5.97)\end{array}$ & $\begin{array}{c}0.00 \\
(2.42)\end{array}$ \\
\hline
\end{tabular}

${ }^{1}$ Based on means from start of sample to year t-1 of INFLATION HISTORY and OPENNESS. ${ }^{2}$ Based on one-year lagged five-year moving average of INFLATION HISTORY and OPENNESS. 
A second study reported in the 1996 WEO compares the determinants of industrialised and developing country inflation using a multi-equation statistical model. It finds exchange rate shocks to be important to inflation in both regions, consistent with the estimated significance of exchange rate variables shown in Table 2 of this paper. The study also finds output gap shocks to be much more important, relative to exchange rate shocks, in the industrialised countries than in the developing countries. Loosely speaking, this would appear to be consistent with the differences in inflation behaviour identified in this paper between Latin America, on the one hand, and Asia and the industrialised countries, on the other. Our results suggest that, if countries are to be aggregated according to their inflation performance, Asian countries might better be grouped with the industrialised countries than with the Latin American countries. ${ }^{12}$

\section{Accounting for differences in inflation behaviour}

In this section, various explanations for the difference in inflation behaviour between the regions are considered. The first possibility, addressed in Section 3.1 below, is that differences in the estimated response of inflation to the real exchange rate are spurious. Under this hypothesis, the equilibrium real exchange rate is more variable in some regions than in others - perhaps reflecting differences in the incidence of productivity shocks - and this makes it more difficult to identify the relationship between inflation and real exchange rates in some regions than in others. The second possibility, discussed in Section 3.2, is that the response of inflation to gaps between the actual and equilibrium real exchange rate really does differ between the regions. A number of factors are considered that might influence this response, including prior inflation experience and the degree of openness of the economy to foreign trade.

\subsection{The role of productivity growth effects}

It is well established in theory that differential rates of sectoral productivity growth may lead to changes in the equilibrium real exchange rate. In a tradables/non-tradables framework, for example, the Balassa-Samuelson effect predicts that higher productivity growth in the tradables than in the non-tradables sector will lead to a decline in the equilibrium ratio of tradables to non-tradables prices - that is, a real appreciation. Similarly, in the foreign goods/home goods framework described in Section 1, as shown in equation (8), weak productivity growth and hence low supply growth in the

12 In a separate study, Hoffmaister and Roldos (1997) apply VAR analysis to macroeconomic performance variables in Latin America and Asia. They find that in both regions inflation is determined largely by domestic nominal shocks, with external shocks and domestic supply shocks having little importance. There is some evidence that fiscal shocks are more important to inflation in Asia than in Latin America, but otherwise little difference in the inflationary process is identified. These results do not conflict with those in this paper - which indicate significant differences in inflationary behaviour between the regions - since in the Hoffmaister and Roldos framework, nominal shocks affect both the exchange rate and the output gap, and no attempt is made to distinguish between the two channels. Conversely, this paper shows that it is the relative importance of exchange rates and output gaps in affecting inflation that differs between regions. 
home goods sector - which is analogous in various respects to the non-tradables sector - relative to absorption will also generate an increase in the relative price of home goods and hence an equilibrium real appreciation.

Since inflation is affected by the gap between the actual and the equilibrium (that is, home goods market-clearing) real exchange rate, if the equilibrium real exchange rate is changing, the response of inflation to the actual real exchange rate may be more difficult to estimate. Consider the $\mathrm{HH}$ curve representing home goods equilibrium in Figure 1. If this is evolving over time, then any given combination of the real exchange rate and aggregate demand - that is, any point on the graph may be associated with excess supply of home goods (and hence deflation) at one point in time, and excess demand (and hence inflation) at another. Unless the factors shifting the $\mathrm{HH}$ curve productivity shocks, shifts in the composition of demand, etc. - are controlled for, it will be difficult to estimate a stable relationship between inflation, the real exchange rate and aggregate demand.

In principle, the equations shown in Table 2, by including the gap between aggregate demand and potential output as an explanatory variable, should control adequately for shocks to productivity: such shocks would be reflected in changes in potential output and hence in the output gap. In practice, however, some of the assumptions used to derive the estimating equation may not hold: actual output may not be a good long-term proxy for absorption, the HP filter measure of potential output may not fully capture productivity movements, or distinctions between productivity growth in the tradables and non-tradables sector - not addressed in the model used in this paper - may be important. Under these circumstances, it might be difficult to identify the true relationship between inflation, the real exchange rate and absorption, and this could lead to low and statistically insignificant coefficients on the real exchange rate variable. To the extent that one region - say, Asia was subject to more and larger productivity shocks than another - say, Latin America - this could lead to a lower estimated responsiveness of inflation to the real exchange rate in the former region compared with the latter.

To test for this possibility, the equations presented in Table 2 were re-estimated using three different proxies for the cumulative effect of differential productivity growth on the equilibrium real exchange rate: (1) a time trend; (2) the cumulated growth of GDP minus the cumulated growth of GDP in G-7 countries, a proxy for differential productivity growth in home and foreign goods; ${ }^{13}$ and (3) the cumulated growth in exports minus the cumulated growth in GDP, a proxy for differential productivity growth in the tradables sector relative to the sum of tradables and non-tradables sectors. The results (not shown) indicated that the first two measures were insignificant in all equations. The third measure was significant only in the Latin America regression and in the "all countries" regression; moreover, its inclusion did not significantly alter the other coefficients in those regressions. Hence, there is no evidence that shifts in the equilibrium real exchange rate resulting from

13 This follows Edwards (1989), who uses GDP growth as a proxy for technological progress in an equation to explain the equilibrium real exchange rate. 
differential productivity growth or other supply-side shocks have led to inaccuracies, or differences across regions, in the estimation results shown in Table $2 .{ }^{14}$

\subsection{The role of inflation history and economic openness}

The results described in Section 3.1 above suggest that estimated differences across regions in the speed of adjustment of prices to gaps between the actual and the equilibrium real exchange rate are not spurious. In this section, we consider two factors that may explain these estimated differences in inflationary response. The first of these is the prior inflation history of a country. Sustained high levels of inflation, as they become embedded in the psychology and institutions of wage and price-setting, may themselves increase the sensitivity of inflation to subsequent inflationary shocks. When inflation is high and variable, the length of wage contracts tends to shorten, prices are revised with greater frequency, and expectations of future inflation become a more important determinant of current wage and price-setting. In these circumstances, factors tending to signal rising prices are likely to induce a greater inflationary response than would be the case in a low-inflation environment. The exchange rate has played a particularly important role in this respect since it is the most visible, frequently adjusted gauge of future movements in aggregate prices. $^{15}$

Hence, an important determinant of the current responsiveness of inflation to exchange rate changes may be the prior history of inflation itself. This prior history is measured in two different ways. First, inflation history is measured as the mean inflation rate in a country from the start of the sample until the year immediately preceding the contemporaneous year. This specification presupposes that inflationary memories are highly persistent. A second measure of inflationary history is the mean inflation rate over the past five years only.

In addition to inflation history, a second possible factor determining the responsiveness of inflation to the exchange rate is the openness of the economy. In principle, a completely closed economy should exhibit no responsiveness of inflation to exchange rate changes, since neither import costs nor export prices would have any bearing on the supply of or demand for domestic products. Conversely, an economy with a high share of foreign trade should be much more sensitive to both the real and the nominal exchange rate.

\footnotetext{
14 This should not be entirely surprising, as evidence for the Balassa-Samuelson effect, or other theories linking productivity growth with real exchange rates, has been mixed. De Gregorio et al. (1994) do find strong evidence that productivity growth affects the real exchange rate in OECD countries. However, Ito et al. (1997) find much weaker evidence for this effect in Asian countries. Moreover, Edwards (1989), in explaining the real exchange rate in a panel of 12 developing countries, found that the coefficient on his proxy for technological progress - GDP growth - actually had the wrong sign, compared with the prediction of the Balassa-Samuelson effect. Finally, in their VAR analysis of Asian and Latin American countries, Hoffmaister and Roldos (1997) find little evidence that real exchange rates are importantly affected by domestic supply shocks.

15 Dornbusch et al. (1990) explore this process in detail. Leiderman and Bufman (1996) also present evidence suggesting that the degree of pass-through from exchange rates to prices is higher in high-inflation countries.
} 
The openness of the economy is defined as the log of the ratio of merchandise imports to GDP. Analogously to the inflation history variable, two measures are calculated: (1) the mean over the entire preceding sample, and (2) the mean over the past five years.

Table 4 indicates estimation results for the basic inflation equation, once the various measures of inflation history and openness are interacted both with the rate of exchange rate depreciation and with the lagged log-level of the real exchange rate. The coefficients on these interaction variables are expected to be positive: a history of higher inflation and a higher degree of openness are expected to increase the responsiveness of inflation to the exchange rate.

Table 4

\section{Tests for inflation history and openness}

Dependent variable: $\Delta \log (P)$

\begin{tabular}{|c|c|c|c|c|c|c|c|c|}
\hline \multirow{3}{*}{$\Delta \log (P)_{-1}$} & \multicolumn{2}{|c|}{ All countries } & \multicolumn{2}{|c|}{ Latin America } & \multicolumn{2}{|c|}{ Asia } & \multicolumn{2}{|c|}{ Industrialised } \\
\hline & (a) & (b) & (a) & (b) & (a) & (b) & (a) & (b) \\
\hline & $\begin{array}{c}0.21 \\
(16.45)\end{array}$ & $\begin{array}{c}0.20 \\
(14.04)\end{array}$ & $\begin{array}{c}0.17 \\
(6.31)\end{array}$ & $\begin{array}{c}0.16 \\
(5.62)\end{array}$ & $\begin{array}{c}0.26 \\
(4.02)\end{array}$ & $\begin{array}{c}0.16 \\
(2.40)\end{array}$ & $\begin{array}{c}0.39 \\
(10.67)\end{array}$ & $\begin{array}{c}0.28 \\
(6.78)\end{array}$ \\
\hline$\Delta \log \left(P^{*}\right)$ & $\begin{array}{c}0.97 \\
(21.50)\end{array}$ & $\begin{array}{r}0.97 \\
(18.95)\end{array}$ & $\begin{array}{c}0.95 \\
(9.64)\end{array}$ & $\begin{array}{l}0.98 \\
(9.21)\end{array}$ & $\begin{array}{c}0.83 \\
(6.99)\end{array}$ & $\begin{array}{c}0.72 \\
(4.75)\end{array}$ & $\begin{array}{r}0.67 \\
(13.03)\end{array}$ & $\begin{array}{c}0.56 \\
(8.75)\end{array}$ \\
\hline$\Delta \log (E)$ & $\begin{array}{c}0.07 \\
(0.87)\end{array}$ & $\begin{array}{r}0.52 \\
(15.39)\end{array}$ & $\begin{array}{c}0.15 \\
(0.83)\end{array}$ & $\begin{array}{c}0.49 \\
(6.87)\end{array}$ & $\begin{array}{l}0.17 \\
(0.68)\end{array}$ & $\begin{array}{l}-0.07 \\
(-0.39)\end{array}$ & $\begin{array}{l}-0.07 \\
(-0.78)\end{array}$ & $\begin{array}{c}0.13 \\
(2.31)\end{array}$ \\
\hline $\log (R E R)_{-1}$ & $\begin{array}{c}0.16 \\
(7.16)\end{array}$ & $\begin{array}{r}0.16 \\
(9.65)\end{array}$ & $\begin{array}{c}0.71 \\
(5.39)\end{array}$ & $\begin{array}{c}0.33 \\
(5.96)\end{array}$ & $\begin{array}{l}0.03 \\
(1.04)\end{array}$ & $\begin{array}{c}0.04 \\
(2.05)\end{array}$ & $\begin{array}{c}0.06 \\
(5.35)\end{array}$ & $\begin{array}{c}0.06 \\
(5.40)\end{array}$ \\
\hline$Y G A P_{-1}$ & $\begin{array}{c}0.28 \\
(3.66)\end{array}$ & $\begin{array}{c}0.26 \\
(3.09)\end{array}$ & $\begin{array}{c}0.44 \\
(1.57)\end{array}$ & $\begin{array}{c}0.59 \\
(2.10)\end{array}$ & $\begin{array}{c}0.40 \\
(4.13)\end{array}$ & $\begin{array}{c}0.47 \\
(4.56)\end{array}$ & $\begin{array}{c}0.17 \\
(4.40)\end{array}$ & $\begin{array}{c}0.22 \\
(5.75)\end{array}$ \\
\hline $\begin{array}{l}\text { INFLATION HISTORY } \mathrm{x} \\
\log (R E R)_{-1}\end{array}$ & $\begin{array}{c}0.13 \\
(9.32)\end{array}$ & $\begin{array}{c}0.03 \\
(5.97)\end{array}$ & $\begin{array}{c}0.04 \\
(1.33)\end{array}$ & $\begin{array}{c}0.02 \\
(2.23)\end{array}$ & $\begin{array}{c}0.09 \\
(1.96)\end{array}$ & $\begin{array}{l}-0.01 \\
(-0.33)\end{array}$ & $\begin{array}{c}0.07 \\
(3.54)\end{array}$ & $\begin{array}{l}-0.03 \\
(-2.52)\end{array}$ \\
\hline $\begin{array}{l}\text { OPENNESS x } \\
\log (R E R)_{-} 1\end{array}$ & $\begin{array}{c}-0.02 \\
(-2.71)\end{array}$ & $\begin{array}{c}0.00 \\
(0.56)\end{array}$ & $\begin{array}{c}-0.16 \\
(-3.92)\end{array}$ & $\begin{array}{c}0.00 \\
(3.06)\end{array}$ & $\begin{array}{c}-0.00 \\
(-0.44)\end{array}$ & $\begin{array}{c}-0.00 \\
(-0.88)\end{array}$ & $\begin{array}{c}0.00 \\
(0.26)\end{array}$ & $\begin{array}{c}0.00 \\
(0.31)\end{array}$ \\
\hline $\begin{array}{l}\text { INFLATION HISTORY } \mathrm{x} \\
\Delta \log (E)\end{array}$ & $\begin{array}{c}0.51 \\
(12.95)\end{array}$ & $\begin{array}{c}0.16 \\
(12.16)\end{array}$ & $\begin{array}{c}0.35 \\
(4.10)\end{array}$ & $\begin{array}{c}0.11 \\
(4.05)\end{array}$ & $\begin{array}{c}0.58 \\
(0.53)\end{array}$ & $\begin{array}{l}1.4 \\
(1.54)\end{array}$ & $\begin{array}{l}2.2 \\
(4.67)\end{array}$ & $\begin{array}{c}0.80 \\
(2.21)\end{array}$ \\
\hline $\begin{array}{l}\text { OPENNESS X } \\
\Delta \log (E)\end{array}$ & $\begin{array}{c}0.12 \\
(4.53)\end{array}$ & $\begin{array}{c}0.00 \\
(0.32)\end{array}$ & $\begin{array}{c}0.16 \\
(2.66)\end{array}$ & $\begin{array}{c}0.00 \\
(2.03)\end{array}$ & $\begin{array}{c}-0.03 \\
(-0.45)\end{array}$ & $\begin{array}{c}0.00 \\
(0.91)\end{array}$ & $\begin{array}{c}-0.00 \\
(-0.04)\end{array}$ & $\begin{array}{c}-0.00 \\
(-2.67)\end{array}$ \\
\hline
\end{tabular}

(a) INFLATION HISTORY $=$ mean $\Delta \log (P)$ from start of sample period to year $\mathrm{t}-1$.

OPENNESS = mean log (imports/GDP) from start of sample period to year $\mathrm{t}-1$.

(b) INFLATION HISTORY = mean $\Delta \log (P)$ from year t-5 to year t-1.

OPENNESS = mean $\log$ (imports/GDP) from year $\mathrm{t}-5$ to year $\mathrm{t}-1$.

The estimation results support the role of past inflation in affecting the contemporaneous response of inflation to both the real exchange rate and nominal exchange rate depreciation. Regardless of which measure of inflation history is used, the coefficients on the interaction terms in 
the regression applied to all countries are positive and significant. ${ }^{16}$ The results are somewhat more mixed in the separate regional regressions. The coefficients on the inflation history terms are usually, but not always, positive, and their statistical significance varies as well.

The regression results provide particularly weak support for the role of openness in conditioning the responsiveness of inflation to the exchange rate. In the equation estimated for all countries, the coefficient on the openness interaction term is positive and significant in only one of four instances. The results for the separate regional regressions are similarly mixed.

While inflation history may help to explain why inflation in some countries is more responsive to the exchange rate than in others, it is not clear that this factor accounts for the entirety of the estimated differences in inflation responsiveness between Latin America, Asia and the industrialised countries. To determine whether inflation history and openness can explain part of the regional differences in inflation responsiveness, the inflation history and openness interaction terms shown in Table 4 were added as explanatory variables in the equation shown in the first column of Table 3 .

The results are presented in the second and third columns of Table 3. They indicate that even after the inflation history and openness interaction terms are added to the equation, differences between Latin America and the other two regions in the estimated response of inflation to the exchange rate - as represented by the coefficient on the regional dummy interaction terms - remain statistically significant. Therefore, whatever factors account for the differences in inflationary behaviour between Latin America, Asia and the industrialised countries, they have not been identified in this analysis.

\section{Conclusion}

Based on the research described above, the following conclusions can be made. First, there clearly is a role for the level of the real exchange rate, along with the output gap, in the determination of inflation in many economies. Even with lagged inflation and the rate of nominal exchange rate depreciation held constant, the coefficient on the lagged real exchange rate was statistically significant in nearly all of the equations that were estimated. This suggests that for many economies, analyses and forecasts of inflation based on Phillips curve type measures alone - such as unemployment rates or output gaps - may be misleading.

The estimated importance of the effect exerted by the real exchange rate may pose a dilemma for policy-makers wishing to achieve both price stability and export competitiveness: not

\footnotetext{
16 The finding that exchange rates exert a stronger influence on inflation in higher-inflation countries is consistent with the finding that tests of purchasing power parity (PPP) are more likely to confirm that PPP holds in high-inflation economies than in low-inflation economies (see surveys by Froot and Rogoff (1995) and Rogoff (1996)).
} 
only will an exchange rate devaluation lead to a temporary increase in inflation, but, if the level of the real exchange rate is maintained at its new, more depreciated level through subsequent nominal devaluations, this may lead to a sustained higher level of inflation as well. Conversely, in countries that have high exchange rate competitiveness but also high rates of inflation, lowering inflation may require some appreciation of the real exchange rate, with a corresponding loss of competitiveness.

The second conclusion supported by the analysis in this paper is that the responsiveness of inflation to the real exchange rate appears to have been much higher in Latin America than either in Asia or in the industrialised countries. This difference in inflationary behaviour may help to explain why exchange rate and macroeconomic policies have been, on balance, more consistent over time in many Asian countries compared with many Latin American countries. In Asia, pronounced real devaluations in the 1980s were not associated with marked upswings in inflation; this allowed Asian countries to keep their real exchange rates depreciated, thereby maintaining competitiveness and encouraging strong export growth.

Conversely, in Latin America, large devaluations in the 1980s - made necessary by balance-of-payments crises - led to sharp increases in inflation. These increases, in turn, forced the authorities in many countries to allow the real exchange rate to appreciate in order to reduce inflation, thereby laying the foundation for subsequent balance-of-payments crises in certain instances. Hence, the inability to combine competitiveness with price stability in Latin America appears to have engendered a certain degree of instability in macroeconomic policy focus.

Finally, the differences in the responsiveness of inflation to the real exchange rate between the regions do not appear to be the result of estimation problems induced by changes in equilibrium real exchange rates, nor are these differences accounted for by the two most obvious possible determinants of inflationary responsiveness: (1) the prior inflation history of a country and (2) the openness of the economy. This suggests that the reasons for different inflationary behaviour in Latin America and Asia may be more deeply rooted in the underlying social, economic and political structures of the two regions. Even so, there appears to be some evidence that prior inflation, by raising the sensitivity of institutions and expectations to inflationary shocks, raises the responsiveness of inflation to exchange rate changes. On the other hand, the evidence that inflation is more responsive to exchange rates in more open economies was fairly mixed. Clearly, further research into the factors underlying differences in inflationary behaviour between Latin America and Asia would be desirable. 


\section{Appendix: Derivation of the supply curve for home goods}

Recall that the price of the foreign good $P_{F}$ is determined by the exchange rate $E$ (local

currency per dollar) and the (exogenous) foreign currency price of foreign goods $P_{F}^{*}$. The price of home goods $P_{H}$ is determined by equilibrium in the market for home goods. ${ }^{17}$ Producers maximise profits by choosing the level of labour use $L$, and hence the level of output $Q_{H}$, subject to declining marginal products of labour for a given level of capacity or potential output $\bar{Q}_{H}$. $\eta_{a, b}$ refers to the elasticity of $a$ with respect to $b$.

$\max P_{H} Q_{H}-W L$

s.t. $Q_{H}=Q_{H}\left(L / \bar{L} ; \bar{Q}_{H}\right)$

$0<\eta_{Q_{H}, L / \bar{L}}<1$ and $\eta_{Q_{H}, \bar{Q}_{H}}=1$

$\bar{Q}_{H}$ is exogenous in this simple framework, but may be thought of as the outcome of a constant returns production function based on exogenous capital $\bar{K}$, an exogenous component to labour supply (reflecting demographic factors, social and legal norms, etc.) $\bar{L}$, and factor-neutral technology T:

$\bar{Q}_{H}=T f(\bar{L}, \bar{K})$

$\eta_{\bar{Q}_{H}, \bar{L}}+\eta_{\bar{Q}_{H}, \bar{K}}=1$

Profit maximisation leads to an implicit function for labour demand as a function of the real product wage:

$L^{d}=L^{d}\left(W / P_{H} ; \bar{Q}_{H}\right)$

$\eta_{L^{d}, W / P_{H}}<0$

Labour supply is assumed to be upward-sloping in the real consumption wage, which is assumed to depend on the consumer price index $P$, a weighted average of home and foreign goods prices. As noted above, labour supply also depends upon an exogenous component $\bar{L}$.

$L^{S}=L^{S}(W / P ; \bar{L})$

$P=P_{H}^{\alpha} P_{F}^{1-\alpha}$

17 This model is similar to Borio and Rankin (1985). Kamin (1996) explains the correlation between the real exchange rate and inflation in Mexico with a very similar model based on traded and non-traded goods. In that model, the real exchange rate represents the ratio of tradables to non-tradables prices, whereas in the model used here, the real exchange rate represents the ratio of foreign to home goods prices. 
$\eta_{L^{S}, W / P}>0$ and $\eta_{L^{S}, \bar{L}}=1$

Equilibrium in the labour market requires that labour demand equal labour supply. We set equations (A3) and (A4) equal to each other and log-differentiate, assuming the level of potential output $\bar{Q}_{H}$ to remain unchanged. It is straightforward to show that in equilibrium, log-changes (denoted by ${ }^{\wedge}$ ) in the real product wage can be expressed as positive function of the growth of foreign goods prices relative to home goods prices. Increases in foreign goods prices raise the cost of living, thereby raising nominal wages relative to home goods prices and hence increasing the real product wage.

$\left(\hat{W}-\hat{P}_{H}\right)=\gamma\left(\hat{P}_{F}-\hat{P}_{H}\right)$

$\gamma=\frac{(1-\alpha) \eta_{L^{S}, W / P}}{\eta_{L^{s}, W / P}-\eta_{L^{d}, W / P}}>0$

On the basis of equation (A5), a supply function for home goods based on the relative price, or equivalently, the real exchange rate $P_{\mathrm{F}} / P_{\mathrm{H}}$, can be written:

$S_{H}=S_{H}\left(P_{F} / P_{H} ; \bar{Q}_{H}\right)$

$\eta_{S_{H}, P_{F} / P_{H}}<0$ and $\eta_{S_{H}, \bar{Q}_{H}}>0$

This is shown as equation (2) in the text. 


\section{References}

Adams, Charles, and Daniel Gros (1986): "The Consequences of Real Exchange Rate Rules for Inflation: Some Illustrative Examples". IMF Staff Papers, Vol. 33, pp.439-76.

Borio, C.E.V. and N. Rankin (1985): "An 'Equilibrium' Theory of the Phillips Curve with Adaptive Expectations: A Simple Treatment for Closed and Open Economies". Unpublished paper, Oxford University.

Calvo, Guillermo A., Carmen M. Reinhart and Carlos A. Vegh (1994): "Targeting the Real Exchange Rate: Theory and Evidence". IMF Working Paper 94/22.

Coe, David T. and C. John McDermott (1996): "Does the Gap Model Work for Asia?" IMF Working Paper 96/69.

De Gregorio, Jose, Alberto Giovannini and Holger C. Wolf (1994): "International Evidence on Tradeables and Nontradeables Inflation". European Economic Review, pp.1225-1244.

Dornbusch, Rudiger, Frederico Sturzenegger and Holger Wolf (1990): "Extreme Inflation: Dynamics and Stabilization". Brookings Papers on Economic Activity, No. 2, pp. 1-84.

Edwards, Sebastian (1989): Real Exchange Rates, Devaluation, and Adjustment: Exchange Rate Policy in Developing Countries, Cambridge, Massachusetts: MIT Press. University Press.

Edwards, Sebastian (1995): Crisis and Reform in Latin America, New York: Oxford

Froot, Kenneth A. and Kenneth Rogoff: "Perspectives on PPP and Long-Run Real Exchange Rates", in G. Grossman and K. Rogoff, eds., (1995), Handbook of International Economics, vol. III, Elsevier Science B.V.

Hoffmaister, Alexander W. and Jorge E. Roldos (1997): "Are Business Cycles Different in Asia and Latin America?" IMF Working Paper 97/9.

International Monetary Fund (1996): World Economic Outlook, Washington, D.C.

Ito, Takatoshi, Peter Isard and Steven Symansky (1997): "Economic Growth and Real Exchange Rate: An Overview of the Balassa-Samuelson Hypothesis in Asia". NBER Working Paper No. 5979.

Kamin, Steven B. (1996): "Real Exchange Rates and Inflation in Exchange-Rate Based Stabilizations: An Empirical Examination". Board of Governors of the Federal Reserve System, International Finance Discussion Paper No. 554.

Kiguel, Miguel A. (1992): "Exchange Rate Policy, the Real Exchange Rate, and Inflation: Lessons from Latin America". The World Bank, Policy Research Working Paper Series No. 880.

Leiderman, Leonardo and Gil Bufman (1996): "Searching for Nominal Anchors in Shock-Prone Economies in the 1990s: Inflation Targets and Exchange Rate Bands". OECD, Paris.

Montiel, Peter J. and Jonothan D. Ostry (1991): "Macroeconomic Implications of Real Exchange Rate Targeting in Developing Countries". IMF Staff Papers, Vol. 38, pp.872-900.

Rogoff, Kenneth (1996): "The Purchasing Power Parity Puzzle". Journal of Economic Literature, Vol. XXXIV, pp.647-668.

Sachs, Jeffrey D. (1985): "External Debt and Macroeconomic Performance in Latin America and East Asia". Brookings Papers on Economic Activity, No. 2, pp. 523-73. 




\section{Recent BIS Working Papers}

No.

29

September 1995

30

November 1995

31

December 1995

32

December 1995

33

January 1996

34

January 1996

35

July 1996

36

August 1996

37

September 1996

38

October 1996

39

January 1997

40

March 1997

41

May 1997

42

June 1997

43

July 1997

44

July 1997
Title

Author

The information content of the term structure: evidence

Stefan Gerlach for Germany

Money demand stability and currency substitution in six European countries (1980-1992)

Testing the quantity theory using long-run averaged cross-country data

The anatomy of the bond market turbulence of 1994

Claudio E.V. Borio

Robert N. McCauley

Benjamin H. Cohen

Derivatives and asset price volatility: a test using variance ratios

Monetary policy and the behaviour of interest rates: are

Stefan Gerlach

long rates excessively volatile?

Varieties of monetary policy operating procedures:

balancing monetary objectives with market efficiency

Estimation of speculative attack models: Mexico yet again

Does the term structure predict recessions?

The international evidence

International agreements in the area of banking and

finance: accomplishments and outstanding issues

Banking system failures in developing and transition countries: diagnosis and prediction

Monetary policy operating procedures industrial countries

The euro and European financial markets

Measuring monetary policy shocks in France, Germany and Italy: the role of the exchange rate

Exchange rate regimes and the expectations hypothesis of the term structure

Is there excess comovement of bond yields between countries?
Stefan Gerlach and Frank Smets

Joseph Bisignano

William R. Melick

Henri Bernard and Stefan Gerlach

William R. White

Patrick Honohan

Claudio E. V. Borio

Robert N. McCauley and William R. White

Frank Smets

Gregory D. Sutton 